\title{
SOME INEQUALITIES FOR THE ČEBYŠEV FUNCTIONAL AND EULER TWO-POINT FORMULAE
}

\section{J. PeČARIĆ AND A. VuKELIĆ}

Abstract. We use inequalities for the Čebyšev functional in terms of the first derivative (see [3]), for some new bounds for the remainder of general Euler two-point formula and its generalization for Bullen type formula.

Mathematics subject classification (2010): 26D15, 26D20, 26D99.

Keywords and phrases: Čebyšev functional, general Euler two-point formula, Bulen type formula, Euler trapezoid formula, Euler midpoint formula, Euler two-point Newton-Cotes formula, Euler two-point Maclaurin formula, Euler bitrapezoid formula.

\section{REFERENCES}

[1] M. Abramowitz And I. A. Stegun (Eds), Handbook of mathematical functions with formulae, graphs and mathematical tables, National Bureau of Standards, Applied Math. Series 55, 4th printing, Washington 1965.

[2] I. S. Berezin ANd N. P. Zhidkov, Computing methods, Vol. I, Pergamon Press, Oxford, 1965.

[3] P. CERone AND S. S. Dragomir, Some new bounds for the Čebyšev functional in terms of the first derivative and applications, J. Math. Ineq. 8 (1) (2014), 159-170.

[4] M. KlariČIĆ BAKUla, J. PeČARIĆ, Generalized Hadamard's inequalities based on general Euler 4-point formulae, ANZIAM J. 48 (2007), 1-18.

[5] J. PeČArić, I. Perić, A. Vukelić, On general Euler two-point formulae, ANZIAM J. 46 (2005), $555-574$.

[6] J. PeČARIĆ, A. VuKelić, Estimations of the error for two-point formula via pre-Grüss inequality, Gen. Math. 13 (2) (2005), 95-104. 